\title{
Familial Occurrence of Dementia and Parkinsonism
}

\author{
A Systematic Review
}

\author{
Martin Wilhelm Kurz ${ }^{\mathrm{a}, \mathrm{c}} \quad$ Anna Melissa Schlitter ${ }^{\mathrm{b}} \quad$ Jan Petter Larsen ${ }^{\mathrm{c}} \quad$ Clive Ballard $^{\mathrm{e}}$ \\ Dag Aarsland ${ }^{\mathrm{d}}$
}

${ }^{a}$ Department of Neurology, Heinrich Heine University Düsseldorf, Düsseldorf, b Department of Human Genetics, Ruhr University Bochum, Bochum, Germany; ${ }^{\mathrm{C}}$ Department of Neurology and ${ }^{\mathrm{d}}$ Psychiatric Clinic, Stavanger University

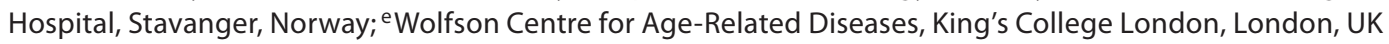

\section{Key Words}

Parkinson's disease with dementia - Dementia with Lewy bodies - Cognitive decline

\begin{abstract}
Parkinson's disease with dementia (PDD) and dementia with Lewy bodies (DLB) are common clinical dementias characterized neuropathologically by the presence of cortical Lewy body pathology and with distinct clinical and neurobiological similarities. Importantly, genetic factors seem to play a key role in the pathogenesis of Parkinson's disease. In the current article, we examine the evidence for a genetic component to DLB and PDD by reviewing studies of familial PDD and DLB as well as familial coincidental PDD and DLB, and report the genes involved. There is a convincing genetic overlap between both syndromes, suggesting that they share a common etiological factor.
\end{abstract}

Copyright $\odot 2006$ S. Karger AG, Basel

\section{Introduction}

Dementia is one of the most common age-related neurodegenerative disorders in the industrialized world. Due to the progressive aging of the Western population, the incidence of late-onset neurodegenerative disorders as- sociated with dementia are increasing dramatically. Over the last decade, exciting recent studies have identified several genes such as presinilin 1 and 2 , apolipoprotein $\varepsilon$ $(\mathrm{APO} \varepsilon)$ and amyloid precursor protein involved in the development of Alzheimer's disease (AD) [1, 2], which have enabled enormous advances in our understanding of the molecular biology of the disease and facilitated the development of novel therapeutic approaches.

In parallel, progress in the study of the genetics of Parkinson's disease (PD) has enhanced our understanding of basic disease mechanisms, for example highlighting the central importance of $\alpha$-synuclein. Mutations in the $\alpha$ synuclein gene (SNCA) give rise to autosomal dominant PD [3], and recently a direct relationship between SNCA dosage and disease progression has been reported [4]. Furthermore mutations in the parkin gene have been found to contribute in the pathogenesis of early onset autosomal recessive parkinsonism, with a wide range of phenotypic features [5-7] The phenotype appears due to partial or complete loss of the parkin protein. Typically nigral degeneration is not accompanied by Lewy body formation. Parkin protein acts as an E3 ubiquitin protein ligase [8] in the ubiquitin-proteasome system. However, proteomic analysis has revealed that parkin may have a neuroprotective effect by maintaining mitochondrial integrity [9-11].

\section{KARGER \\ Fax +4161306 1234 E-Mail karger@karger.ch} www.karger.com
(C) 2006 S. Karger AG, Basel

$1420-8008 / 06 / 0224-0288 \$ 23.50 / 0$

Accessible online at:

www.karger.com/dem
Dag Aarsland

Psychiatric Clinic, Stavanger University Hospital

Armauer Hansensvei 20

NO-4011 Stavanger (Norway)

Tel. +47 5151 5210, Fax +47 5151 5205, E-Mail DAA@sir.no 
The cumulative frequency of dementia in PD has been shown to be as high as 78\% [12]. Although there is some inconsistency in the literature, the results from recent studies on balance indicate that limbic and cortical Lewy bodies are the main cause of dementia in PD [1315]. Dementia is a key symptom for PD patients as it increases the risk of nursing home admission [16], mortality [17], and has a substantial impact on the quality of life. Given the prevalence of PD and the frequency of dementia in $\mathrm{PD}$, the approximate frequency of $\mathrm{PD}$ with dementia (PDD) in the population older than 65 years is $0.5 \%$ [18]. Dementia with Lewy bodies (DLB) is the second most common form of neurodegenerative dementia following $\mathrm{AD}$, accounting for $10-20 \%$ of patients with late-onset dementia $[19,20]$. DLB is characterized by parkinsonism, visual hallucinations and cognitive fluctuations. The clinical, neuropsychological and neuropathological similarities of PDD and DLB underline the close relation between the two diseases and support a model where both diseases are seen as part of a spectrum of dementias with cortical Lewy bodies. According to current classification, PDD is diagnosed if PD symptoms develop before the onset of dementia, whereas DLB is diagnosed if dementia precedes or occurs simultaneously with motor symptoms $[21,22]$. Little is known regarding the familial incidence and genetic predisposition of PDD and DLB.

In the current report, we analyze the available studies of genetics in PDD and DLB to determine (1) familial occurrence and genetics of dementia in PD; (2) familial occurrence and genetics in DLB; (3) whether there is evidence of genetic overlap between PDD and DLB, and (4) which genes are involved in PDD/DLB.

\section{Methods}

A systematic literature search from October to December 2005 was performed using the entire time scale of PubMed without using any language restrictions. Mixtures of the following key words with a limit to dementia or cognitive decline and familial or genes were used to perform multiple searches: Parkinson* $\left.{ }^{*} \mathrm{MeSH}\right)$, Lewy body (MeSH), DLB (MeSH). We identified 822 titles and abstracts addressing familial parkinsonism and 78 titles describing familial occurrence of parkinsonism and dementia. We excluded 50 studies that did not fulfill the inclusion criteria. Of the 28 included studies, 14 focused on PDD, 7 reported people with DLB and 8 studies included family members with either PDD/ DLB (one study describes two families with distinct classifications). Cases reported in multiple publications were whenever possible combined in order to avoid reiterations.

Inclusion criteria were: (1) Original study reporting of familial occurrence of Parkinsonism and prominent dementia and
(2) pathological findings compatible with PD, PDD or DLB or (3) clinical findings compatible with PD, PDD or DLB (if autopsy was not performed).

\section{Results}

Results of genetic testing are listed in brackets at the end of each section and in table 1 .

\section{Studies of Familial PDD}

An early study proposed a new neurological genetic disorder, describing a family with dominant inheritance of parkinsonism combined with severe dementia [23], indicating a connection between the two syndromes. A larger study looking at general influence of genes in 71 people with sporadic PD confirmed this coincidence of dementia and parkinsonism. Older age and familial occurrence of dementia were identified as risk factors for the development of dementia in PD. Thirty percent of PD patients with dementia (17 patients) reported a familial occurrence of dementia compared to only $5.6 \%$ of PD patients without dementia. No difference was seen in environmental exposure, personal habits, or medical or surgical illness [24]. (Genetic testing not performed.)

A genetic susceptibility to a syndrome presenting with both PD and dementia was also reported in a large family (Contursi kindred) with 60 affected individuals spanning 5 generations [25-27]. Precise time of onset of dementia was not available, but developed typically after the onset of parkinsonism. Hallucinations and delusions were common. (A53T SNCA mutation.)

Concurrent PD and dementia were also apparent in a family (Iowa kindred) with 22 affected individuals spanning 6 generations [28-31]. All affected members had early-onset PD (mean onset 34 years), weight loss and rapidly progressive L-dopa-responsive parkinsonism followed by hypotension and dementia (mean age of onset, 49 years) including impairment of orientation and visuospatial dysfunction in the course of the disease. Hallucinations were reported in only 1 individual. According to current diagnostic criteria [22, 32], these patients should be classified as PDD. [Inferred haplotype on chromosome 4p (PARK4). SNCA triplication.]

Ishikawa et al. [33] and Wakabayashi et al. [34] describe a Japanese woman who married her uncle (family A). Both developed parkinsonism and the subsequent onset of dementia. Interestingly, both developed a neuroleptic malignant syndrome in the course of their disease. Their two sons developed similar parkinsonism at the 
Table 1. Clinical, neuropathological and genetic results in reported families

\begin{tabular}{|c|c|c|c|c|c|c|c|c|}
\hline \multirow[t]{2}{*}{ Study by } & \multicolumn{2}{|c|}{ Clinical information } & \multicolumn{2}{|c|}{ Categorization } & \multicolumn{3}{|c|}{ Neuropathology } & \multirow[t]{2}{*}{ Genetic findings } \\
\hline & affected & families & PDD & DLB & autopsied & $\mathrm{AD}$ & Lewy bodies & \\
\hline $\begin{array}{l}\text { Globe et al., 1990, 1996; } \\
\text { Duda et al., } 2002\end{array}$ & 60 & 1 & yes & no & 2 & 0 & $(+2) ;^{\mathrm{SN}+\mathrm{NC}}$ & A53T SNCA mutation \\
\hline $\begin{array}{l}\text { Waters and Miller, 1994; } \\
\text { Muenter et al., 1998; } \\
\text { Farrer et al., 1999; } \\
\text { Singleton et al., } 2003\end{array}$ & 22 & 1 & yes & no & 6 & 0 & $(+6) ;^{\mathrm{SN}+\mathrm{NC}}$ & $\begin{array}{l}\text { Inferred haplotype on } \\
\text { chromosome } 4 \text { p (PARK4); } \\
\text { SNCA triplication. }\end{array}$ \\
\hline $\begin{array}{l}\text { Ishikawa et al., 1997; } \\
\text { Wakabayashi et al., } 1998\end{array}$ & 4 (fam. A) & 1 & yes & no & 2 & 0 & Fam. A $(+2) ;{ }^{N N+N C}$ & Fam. A: APO $\varepsilon 3 / 4$ and $\varepsilon 4 / 4$ \\
\hline Ohara et al., 1999 & 4 & 1 & yes & no & 1 & 0 & $(+1) ;{ }^{\mathrm{SN}}+\mathrm{NC}$ & No mutations found \\
\hline Spira et al., 2001 & 5 & 1 & yes & no & 2 & 0 & $(+1) ;{ }^{S N+N C} ;(1)^{S N}$ & A53T SNCA mutation \\
\hline Ohtake et al., 2004 & 1 & 1 & yes & no & 0 & - & Autopsy not performed & V70M $\beta$-synuclein mutation \\
\hline Galvin et al., 2002 & $\begin{array}{l}2(\text { fam. 1) } \\
2(\text { fam. } 2)\end{array}$ & $\begin{array}{l}1 \\
1\end{array}$ & $\begin{array}{l}\text { yes } \\
\text { no }\end{array}$ & $\begin{array}{l}\text { yes } \\
\text { yes }\end{array}$ & $\begin{array}{l}2 \\
2\end{array}$ & $\begin{array}{l}\text { no } \\
(+2)\end{array}$ & $\begin{array}{l}(+2) \mathrm{SN}+\mathrm{NC} \\
(+2))^{\mathrm{SN}+\mathrm{NC}}\end{array}$ & No mutations found \\
\hline Krüger et al., 1998, 2001 & 5 & 1 & no & yes & 0 & - & $\begin{array}{l}\text { Autopsy not } \\
\text { performed }\end{array}$ & $\begin{array}{l}\text { A30P } S N C A \text { mutation } \\
\text { APO } \varepsilon 3 / \varepsilon 3, \text { APO } 33 / \varepsilon 4 \\
\text { Tyr18 allele (UCHL1) }\end{array}$ \\
\hline Brett et al., 2002 & 2 & 1 & no & yes & 2 & 0 & $(+2) ;{ }^{\mathrm{SN}+\mathrm{NC}}$ & Genetic testing not performed \\
\hline Tsuang et al., 2002 & $\begin{array}{l}8 \text { (fam. 1) } \\
6 \text { (fam. } 2)\end{array}$ & $\begin{array}{l}1 \\
1\end{array}$ & $\begin{array}{l}\text { no } \\
\text { no }\end{array}$ & $\begin{array}{l}\text { yes } \\
\text { yes }\end{array}$ & $\begin{array}{l}3 \\
2\end{array}$ & $\begin{array}{l}(+1) \\
(+1) \\
\end{array}$ & $\begin{array}{l}(+2)^{\mathrm{SN}+N C} ;(1)^{\mathrm{AM}} \\
(+2)^{\mathrm{SN}+N C} ;(1)^{\mathrm{AM}}\end{array}$ & $\begin{array}{l}\mathrm{APO} \varepsilon 3 / \varepsilon 4, \mathrm{APO} \varepsilon 4 / \varepsilon 4 \\
\mathrm{APO} \varepsilon 3 / \varepsilon 4, \mathrm{APO} \varepsilon 4 / \varepsilon 4\end{array}$ \\
\hline $\begin{array}{l}\text { Bonner et al., 2003; } \\
\text { Ohtake et al., } 2004\end{array}$ & 8 & 1 & no & yes & 1 & $(+1)$ & $(+1) ;{ }^{\mathrm{SN}+\mathrm{NC}}$ & $\mathrm{P} 123 \mathrm{H} \beta$-synuclein mutation \\
\hline $\begin{array}{l}\text { Denson and Wszolek 1995; } \\
\text { Denson et al., } 1997\end{array}$ & 80 & 8 & yes & yes & 14 & 0 & $(+1) ;^{\mathrm{SN}+\mathrm{NC}}$ & $\begin{array}{l}\text { Linkage to chromosome } 17 \\
\text { (PPND family) }\end{array}$ \\
\hline Ishikawa et al., 1997 & 3 (fam. S) & 1 & yes & yes & 0 & - & Autopsy not performed & Genetic testing not performed \\
\hline $\begin{array}{l}\text { Inose et al., 1988; } \\
\text { Mizutani et al., 1993, } 1997\end{array}$ & 6 & 1 & yes & yes & 2 & 0 & $(+2) ;$ brainstem & Genetic testing not performed \\
\hline Zarranz et al., 2004 & 5 & 1 & yes & yes & 1 & 0 & $(+1) ;{ }^{\mathrm{SN}+\mathrm{NC}}$ & E46K SNCA mutation \\
\hline
\end{tabular}

Persons affected denominated with numbers. Fam. = family; SN = substantia nigra; NC = neocortex; AM = amygdala only; UCHL1 = ubiquitin C-terminal hydrolaseL1; SNCA $=\alpha$-synuclein gene; APO $\varepsilon=$ apolipoprotein $\varepsilon$.

ages of 39 and 28. Parkinsonism was accompanied by autonomic failure; dementia presented several years after onset of parkinsonism and was accompanied by hallucinations and delusions. (Family A: APO $\varepsilon 3 / 4$ and $\varepsilon 4 / 4$.)

In another study, 1 patient died at the age of 51 after a history of dementia and parkinsonism [35]. Among 3 existing siblings, 2 were diagnosed as probable and 1 as possible DLB, although dementia (mean age of onset 45 years) developed late in the course of the disease (mean age of onset of parkinsonism, 35 years) and would be classified as PDD. The patient's sister showed compulsive behavior and the other two siblings had parkinsonism. All showed progressive dementia with a progressive para- phasia and word finding difficulties. Psychotic features, such as persecutory delusions (all), visual hallucinations (2) and sexually disinhibited behavior (2) were also present. Treatment of parkinsonism with L-dopa was effective in 1 individual, but of limited benefit in the others. (No mutations found.)

Familial occurrence of PD and dementia was also diagnosed in an Australian family of Greek origin where 5 of 9 siblings in 1 generation were affected with a L-dopa responsive parkinsonism (mean age of onset, 45 years) and progressive cognitive decline (mean age of onset, 51 years) [36]. Additionally, severe central hypoventilation, orthostatic hypotension, prominent myoclonus and uri- 
nary incontinence were present. Two individuals exhibited psychotic features including paranoia (both) and hallucinations (1). (A53T SNCA mutation.)

Finally, a recent study reported an 83-year-old man with apparently sporadic PDD [37]. PD symptoms developed at the age of 78 that responded well to L-dopa. $\mathrm{He}$ also displayed fluctuating dementia, visual hallucinations and cognitive impairment with unclear time of onset. A mutation in the $\beta$-synuclein gene was identified in this individual. (V70M $\beta$-synuclein mutation.)

\section{Studies of Familial DLB}

There have been only a handful of studies of the familial occurrence of DLB. Two families with co-occurrence of parkinsonism and dementia are described by Galvin et al. [38], but the subjects met the clinical criteria for DLB in only one of the families (family 2). In this family, mother and son were affected. The son presented at age 56 with a progressive cognitive decline without hallucinations. At age 61, bradykinesia and gait changes occurred followed by rigidity. He died 9 years after disease onset. His mother presented at age 85 with progressive cognitive decline including paranoid delusions. Visual hallucinations were not present. At the age of 89 years, she showed very mild rigidity and died at age 91 without prominent parkinsonism. (No mutations found.)

A German family exhibited familial PD with mean disease onset at 59.7 years with a high variability (54-76 years) $[39,40]$. Five individuals in 5 generations were affected. Beside the high variability in disease onset, a milder phenotype and early onset of dementia were remarkable. All examined mutation carriers exhibited deficits in visuoconstructive functions. In 1 patient, visual hallucination developed. As cognitive decline in the affected cases begins early in the course of the disease or is the starting symptom, these cases should be considered as DLB. [A30P SNCA mutation, $\mathrm{APO} \varepsilon 3 / \varepsilon 3, \mathrm{APO} \varepsilon 3 / \varepsilon 4$, Tyr18 allele (ubiquitin C-terminal hydrolase L1).]

Two siblings from a family in Ireland developed progressive parkinsonism and dementia with visual hallucinations [41]. The first patient presented with parkinsonism and developed a fluctuating cognitive deficit with unclear time of onset, the other person experienced a slow and steady decline in cognitive and physical functions and visual hallucinations. As mental and physical decline began contemporaneously, this case should be considered as DLB. Both showed little or no response to L-dopa. Their mother died in the middle of her 4th decade, while no other neurological deficit was found in the family history. (Genetic testing not performed.)

Familial Occurrence of Dementia and Parkinsonism
Another report investigated 2 families with two or more autopsy-proven cases of DLB and a positive family history of dementia [42]. In family 1, 8 affected individuals in 2 generations exhibited dementia as their first neuropsychiatric symptom; 5 developed subsequent parkinsonism and 4 experienced psychiatric symptoms. In family 2, 6 affected individuals in 1 generation presented with cognitive decline, 4 developed parkinsonism but none developed hallucinations or delusions. (Family 1 and 2: $\mathrm{APO} \varepsilon 3 / \varepsilon 4, \mathrm{APO} \varepsilon 4 / \varepsilon 4$.)

Another study investigated a 64-year-old male with dementia, parkinsonism and hallucinations $[37,43]$. At the age of 61, he started recognizing memory deficits and deterioration in handwriting. The cognitive decline progressed, while parkinsonism became obvious at the age of 73. His family history revealed 8 relatives with a history of dementia, including 4 with subsequent parkinsonism fulfilling consensus criteria for possible or probable DLB. (P123H $\beta$-synuclein mutation.)

\section{Studies Reporting Families with Both PDD and DLB}

Several families with DLB and PDD phenotypes have been reported. Eight large kindreds from North America have been described $[44,45]$. In family G, a family with 10 affected members across 3 generations, 4 individuals were examined clinically. Four individuals had an Ldopa-responsive parkinsonism without dementia, 3 individuals presented with dementia followed by parkinsonism, and 3 developed dementia. The mean age of onset of parkinsonism was 57 years, and mean age of onset of dementia was 74 years. In family $\mathrm{F}$, affected individuals presented also with dementia. Exact information about onset of dementia is not given in the other described families. [Linkage to chromosome 17 (PPND family).]

Ishikawa et al. [33] described a family (3 generations) where 1 individual reported an affected grandfather exhibiting gradually progressing bradykinesia (family S); the father developed memory loss from the age of 35 and PD symptoms from the age of 44 , and thus fulfilled criteria for possible DLB. The investigated individual showed juvenile parkinsonism from the age of 34 , and cognitive decline developed 6 years after onset of PD. L-dopa-induced dyskinesias and choreic movement and a neuroleptic malignant syndrome were present. (Genetic testing not performed in family $S$.)

Co-occurrence of DLB and PDD syndromes was reported in a family with 6 affected individuals spanning 3 generations $[46,47]$. Four patients were clinically evaluated. All individuals exhibited PD features and subsequent dementia. In 2 of the patients, dementia was recog-

Dement Geriatr Cogn Disord 2006;22:288-295 
nized in the 1st year of PD symptoms (i.e. DLB), and in 1 patient dementia developed at a later stage of the disease [46] (i.e. PDD). In 1 patient, no information was given about onset of dementia. All patients developed autonomic failure, myoclonic jerks and two of them had general convulsions. Pyramidal tract signs were positive. (Genetic testing not performed.)

The second family (family 1) described by Galvin et al. [38] involved also mother and son. The son presented at age 45 with parkinsonism. Seven years after onset of PD symptoms, dementia was apparent accompanied by visual hallucinations, misperceptions and fluctuations. His mother was evaluated initially at the age of 75 with mild cognitive impairment leading to diagnosis of mild AD. Over the next 2 years, progressive cognitive decline with visual hallucinations and delusions occurred. Postural instability and gait impairment were present. (No mutations found.)

Finally, a 69-year-old man with parkinsonism, memory loss and agitated nocturnal sleep from the age of 67 was described (i.e. DLB) [48]. Initial response to L-dopa was good but choreic dyskinesias developed. Cognition deteriorated and he developed delusions, visual hallucinations and confusion of reality. Four siblings exhibited parkinsonism and dementia, 2 accompanied with hallucinations. In 2 individuals, cognitive impairment developed 2 years after onset of motor symptoms (i.e. PDD), and in 2 the precise onset of dementia was not described. (E46K, SNCA mutation.)

\section{Discussion}

This review of the literature identifies the familial occurrence of coincidental parkinsonism and dementia in 24 families (table 1), 12 of which involved presentations of both DLB and PDD. Differentiation between familial PDD and familial DLB often deviates from the established diagnostic guidelines [21, 22, 32], hence the published pedigree probably underestimates the overlap, which strongly suggests that at least a substantial proportion of these families have the same underlying pathophysiology. As this is clearly the situation in people with familial presentations of DLB or PDD, it is likely that the same will be true of sporadic presentations. This strongly implies that the arbitrary distinction between DLB and PDD based upon the presentation of parkinsonism prior to dementia does not reflect the molecular biology of the disease process and is contrary to the scientific evidence [49]. This point is further emphasized by reports of fam- ilies including individuals with PDD and DLB phenotypes within the same cohort carrying the same mutation. For example, in the study by Zarranz et al. [48], all patients carried the E46K mutation but only the index patient developed dementia within the timeframe to meet diagnostic criteria for DLB. Two siblings developed cognitive decline after 2 years of onset of motor symptoms and thus have to be classified as PDD.

This point of view is strengthened by a recent study that proposes a direct correlation between SNCA dosage and disease progression, i.e. age at onset of parkinsonism and development of dementia in PD patients [4], indicating that the degree of genetic alteration is determining clinical severity. However, a recently completed study failed to identify SNCA multiplication in 101 familial PD probands, 325 sporadic PD cases and 65 patients with $\mathrm{DLB}$, indicating that $S N C A$ multiplications remain a rare cause for familial forms of $\mathrm{PD}[3,50]$. However, the pathogenic relevance of SNCA is underlined by the fact that $\alpha$-synuclein is a substantial component of Lewy bodies in familial and sporadic PD [51].

Collectively, the known and unknown genetic PD cases are likely to explain no more than $5-10 \%$ of the overall $\mathrm{PD}$ population. However, they contribute significantly to our understanding of the molecular biology of both familial and sporadic PD cases with huge therapeutic potential for the patients. In the recent years, the number of genes contributing to the pathogenesis of PD have increased $[7,52,53]$. Interestingly, patients meeting diagnosis criteria for DLB so far display either mutations in the synuclein gene or show positive correlations with APO (table 1). $\alpha$-Synuclein is the main component of Lewy bodies, and regularly the gene results in a presynaptic protein of 140 amino acids that is abundant in the brain and may have lipid binding properties [54]. Three mutations have so far been found in the SNCA that lead to the misfolding of the protein and subsequent protein aggregation in the Lewy bodies (A53T, A30P, E46K). Hypotheses based upon the molecular evidence have proposed that an underlying molecular abnormality leads to a $\alpha$ synuclein aggregation and subsequent cell loss. Most families reported carry the A53T mutation with a typical presentation with early onset of parkinsonism. The mutation consists in the transversion at the nucleotide position 209 from guadenine to adenine, leading to the change of alanine to threonine in the mutant protein [3]. Dementia is seen in the later course of the disease, although it may also be the presenting feature in some individuals. Additional features may include central hypoventilation, postural hypotension, bladder incontinence and myoclo- 
nus $[26,36]$. The mechanisms of increased aggregation of $\alpha$-synuclein in individuals carrying the A53T mutation are still not fully understood, although iron-induced mechanisms are discussed [55-57]. The A30P mutation involves the substitution of guanine to cytosine at position 88 resulting in the change of alanine to proline [40]. Affected individuals have typical L-dopa-responsive parkinsonism except for early-onset dementia. Likewise, carriers of the E46K mutation [48] usually display cognitive decline at an early stage of the disease and show extensive cortical Lewy body pathology. The E46K mutation increases phospholipid binding and assembly into filaments of $\alpha$-synuclein. Thus, three different mutations in the same gene are leading to accumulation of $\alpha$-synuclein and Lewy bodies, strengthening the hypothesis that $\alpha$-synuclein accumulation is key to the subsequent development of dementia.

The discovery of mutations in the gene for leucine-rich kinase 2 (LRRK2) has, however, complicated interpretation. The current findings suggest that mutations in the $L R R K 2$ gene are the most common genetic cause of lateonset PD, accounting for approximately $8 \%$ of cases [58]. Affected individuals display clinical findings typical for sporadic PD without development of cognitive decline (except one case developing severe dementia after a disease duration of $>20$ years [59]). However, the pathomorphologic picture is remarkably variable, ranging from pure degeneration without Lewy bodies to degeneration with brainstem Lewy bodies, widespread Lewy bodies fitting the pattern seen in DLB, and neurofibrillary taupositive tangles [60-62]. At present, it still has to be determined how mutations in the LRRK2 gene cause PD and why neuropathologic findings fitting DLB are not accompanied by dementia.

Consequently, other influences like neurochemical effects as the cholinergic deficit have to interplay as well, causing the clinical picture with early cognitive decline and development of neuropsychiatric deficits like hallucinations.

The APO 44 allele is associated with an increase in the number of neocortical Lewy bodies and amyloid plaques in patients with PD [63], and recent evidence supports that the APO 44 allele may be an independent risk factor in the development of Lewy bodies and dementia in PD $[42,64]$. Primarily, the APO 44 allele is known to be associated with familial and sporadic late-onset $\mathrm{AD}[65$, 66]. As an additional effect, coincident significant AD pathology as seen in DLB patients may increase or accelerate symptom severity. However, in the presented familial studies coincidental AD pathology is only found in the minority of people with dementia (table 1), and a recent study showed that there is no correlation between occurrence of $\mathrm{PD}$ and $\mathrm{AD}$ in the subject's family [67].

Further correlations of clinical, pathomorphological and genetic evidence are needed to elaborate further insights into the molecular biology of dementia in PD, thus creating new chances of developing novel treatment approaches.

\section{References}

$D_{1}$ Zhang P, Wang L, Yang Z, Jin F: Associated genes for dementia of the Alzheimer type. Yi Chuan 2003;25:445-449.

-2 Marechal L, Campion D, Hannequin D: Familial forms of Alzheimer's disease. Presse Med 2003;32:756-763.

-3 Polymeropoulos MH, Lavedan C, Leroy E, Ide SE, Dehejia A, Dutra A, Pike B, Root H, Rubenstein J, Boyer R, Stenroos ES, Chandrasekharappa S, Athanassiadou A, Papapetropoulos T, Johnson WG, Lazzarini AM, Duvoisin RC, Di Iorio G, Golbe LI, Nussbaum RL: Mutation in the alpha-synuclein gene identified in families with Parkinson's disease. Science 1997;276:2045-2047.

\section{$>$}

4 Chartier-Harlin MC, Kachergus J, Roumier C, Mouroux V, Douay X, Lincoln S, Levecque C, Larvor L, Andrieux J, Hulihan M, Waucquier N, Defebvre L, Amouyel P, Farrer M, Destee A: Alpha-synuclein locus duplication as a cause of familial Parkinson's disease. Lancet 2004;364:1167-1169.

5 Abbas N, Lucking CB, Ricard S, Durr A, Bonifati V, De Michele G, Bouley S, Vaughan JR, Gasser T, Marconi R, Broussolle E, BrefelCourbon C, Harhangi BS, Oostra BA, Fabrizio E, Bohme GA, Pradier L, Wood NW, Filla A, Meco G, Denefle P, Agid Y, Brice A: A wide variety of mutations in the parkin gene are responsible for autosomal recessive parkinsonism in Europe. French Parkinson's Disease Genetics Study Group and the European Consortium on Genetic Susceptibility in Parkinson's Disease. Hum Mol Genet 1999;8:567-574.
6 Lucking CB, Abbas N, Durr A, Bonifati V, Bonnet AM, de Broucker T, De Michele G, Wood NW, Agid Y, Brice A: Homozygous deletions in parkin gene in European and North African families with autosomal recessive juvenile parkinsonism. The European Consortium on Genetic Susceptibility in Parkinson's Disease and the French Parkinson's Disease Genetics Study Group. Lancet 1998;352:1355-1356.

7 Gasser T: Overview of the genetics of parkinsonism. Adv Neurol 2003;91:143-152.

-8 Shimura H, Hattori N, Kubo S, Mizuno Y, Asakawa S, Minoshima S, Shimizu N, Iwai K, Chiba T, Tanaka K, Suzuki T: Familial Parkinson disease gene product, parkin, is a ubiquitin-protein ligase. Nat Genet 2000;25: 302-305. 
$>9$ Greene JC, Whitworth AJ, Kuo I, Andrews LA, Feany MB, Pallanck LJ: Mitochondrial pathology and apoptotic muscle degeneration in Drosophila parkin mutants. Proc Natl Acad Sci USA 2003;100:4078-4083.

$>10$ Palacino JJ, Sagi D, Goldberg MS, Krauss S, Motz C, Wacker M, Klose J, Shen J: Mitochondrial dysfunction and oxidative damage in parkin-deficient mice. J Biol Chem 2004;279:18614-18622.

-11 Pesah Y, Pham T, Burgess H, Middlebrooks B, Verstreken P, Zhou Y, Harding M, Bellen H, Mardon G: Drosophila parkin mutants have decreased mass and cell size and increased sensitivity to oxygen radical stress. Development 2004;131:2183-2194.

12 Aarsland D, Andersen K, Larsen JP, Lolk A, Kragh-Sorensen P: Prevalence and characteristics of dementia in Parkinson disease: an 8-year prospective study. Arch Neurol 2003;60:387-392.

13 Parkkinen L, Kauppinen T, Pirttila T, Autere JM, Alafuzoff I: Alpha-synuclein pathology does not predict extrapyramidal symptoms or dementia. Ann Neurol 2005;57:82-91.

14 Aarsland D, Perry R, Brown A, Larsen JP, Ballard C: Neuropathology of dementia in Parkinson's disease: a prospective, community-based study. Ann Neurol 2005;58:773776 .

15 Apaydin H, Ahlskog JE, Parisi JE, Boeve BF, Dickson DW: Parkinson disease neuropathology: later-developing dementia and loss of the levodopa response. Arch Neurol 2002; 59:102-112.

-16 Aarsland D, Larsen JP, Tandberg E, Laake K: Predictors of nursing home placement in Parkinson's disease: a population-based, prospective study. J Am Geriatr Soc 2000;48: 938-942.

$>17$ Levy G, Tang MX, Louis ED, Cote LJ, Alfaro B, Mejia H, Stern Y, Marder K: The association of incident dementia with mortality in PD. Neurology 2002;59:1708-1713.

-18 Aarsland D, Zaccai J, Brayne C: A systematic review of prevalence studies of dementia in Parkinson's disease. Mov Disord 2005;20: 1255-1263.

$\checkmark 19$ Crystal HA, Dickson DW, Lizardi JE, Davies P, Wolfson LI: Antemortem diagnosis of diffuse Lewy body disease. Neurology 1990;40: 1523-1528.

20 McKeith IG, Galasko D, Wilcock GK, Byrne EJ: Lewy body dementia - diagnosis and treatment. Br J Psychiatry 1995;167:709717.

-21 McKeith IG, Galasko D, Kosaka K, Perry EK, Dickson DW, Hansen LA, Salmon DP, Lowe J, Mirra SS, Byrne EJ, Lennox G, Quinn NP, Edwardson JA, Ince PG, Bergeron C, Burns A, Miller BL, Lovestone S, Collerton D, Jansen EN, Ballard C, de Vos RA, Wilcock GK, Jellinger KA, Perry RH: Consensus guidelines for the clinical and pathologic diagnosis of dementia with Lewy bodies (DLB): report of the consortium on DLB international workshop. Neurology 1996;47:1113-1124.
22 McKeith IG, Dickson DW, Lowe J, Emre M, O’Brien JT, Feldman H, Cummings J, Duda JE, Lippa C, Perry EK, Aarsland D, Arai H, Ballard CG, Boeve B, Burn DJ, Costa D, Del Ser T, Dubois B, Galasko D, Gauthier S, Goetz CG, Gomez-Tortosa E, Halliday G, Hansen LA, Hardy J, Iwatsubo T, Kalaria RN, Kaufer D, Kenny RA, Korczyn A, Kosako K, Lee VM, Lees A, Litvan I, Londos E, Lopez OL, Minoshima S, Mizuno Y, Molina JA, Mukaetove-Ladinska EB, Pasquier F, Perry RH, Schulz JB, Trojanowski JQ, Yamada M: Diagnosis and management of dementia with Lewy bodies. Third report of the DLB consortium. Neurology 2005;65:18631872.

23 Rosenberg RN, Green JB, White CL, 3rd, Sparkman DR, DeArmond SJ, Kepes JJ: Dominantly inherited dementia and parkinsonism, with non-Alzheimer amyloid plaques: a new neurogenetic disorder. Ann Neurol 1989;25:152-158.

24 Marder K, Flood P, Cote L, Mayeux R: A pilot study of risk factors for dementia in Parkinson's disease. Mov Disord 1990;5:156-161.

25 Golbe LI, Di Iorio G, Bonavita V, Miller DC, Duvoisin RC: A large kindred with autosomal dominant Parkinson's disease. Ann Neurol 1990;27:276-282.

26 Golbe LI, Di Iorio G, Sanges G, Lazzarini AM, La Sala S, Bonavita V, Duvoisin RC: Clinical genetic analysis of Parkinson's disease in the Contursi kindred. Ann Neurol 1996;40:767-775.

27 Duda JE, Giasson BI, Mabon ME, Miller DC, Golbe LI, Lee VM, Trojanowski JQ: Concurrence of alpha-synuclein and tau brain pathology in the Contursi kindred. Acta Neuropathol (Berl) 2002;104:7-11.

28 Waters $\mathrm{CH}$, Miller CA: Autosomal dominant Lewy body parkinsonism in a four-generation family. Ann Neurol 1994;35:59-64.

29 Muenter MD, Forno LS, Hornykiewicz O, Kish SJ, Maraganore DM, Caselli RJ, Okazaki H, Howard FM Jr, Snow BJ, Calne DB: Hereditary form of parkinsonism-dementia. Ann Neurol 1998;43:768-781.

30 Farrer M, Gwinn-Hardy K, Muenter M, DeVrieze FW, Crook R, Perez-Tur J, Lincoln S, Maraganore D, Adler C, Newman S, MacElwee K, McCarthy P, Miller C, Waters C, Hardy J: A chromosome 4p haplotype segregating with Parkinson's disease and postural tremor. Hum Mol Genet 1999;8:8185.

31 Singleton AB, Farrer M, Johnson J, Singleton A, Hague S, Kachergus J, Hulihan M, Peuralinna T, Dutra A, Nussbaum R, Lincoln S, Crawley A, Hanson M, Maraganore D, Adler C, Cookson MR, Muenter M, Baptista M, Miller D, Blancato J, Hardy J, Gwinn-Hardy $\mathrm{K}$ : alpha-Synuclein locus triplication causes Parkinson's disease. Science 2003;302:841.
32 Gelb DJ, Oliver E, Gilman S: Diagnostic criteria for Parkinson disease. Arch Neurol 1999;56:33-39.

33 Ishikawa A, Takahashi H, Tanaka H, Hayashi T, Tsuji S: Clinical features of familial diffuse Lewy body disease. Eur Neurol 1997; 38(suppl 1):34-38.

34 Wakabayashi K, Hayashi S, Ishikawa A, Hayashi T, Okuizumi K, Tanaka H, Tsuji S, Takahashi H: Autosomal dominant diffuse Lewy body disease. Acta Neuropathol (Berl) 1998;96:207-210.

35 Ohara K, Takauchi S, Kokai M, Morimura Y, Nakajima T, Morita Y: Familial dementia with Lewy bodies (DLB). Clin Neuropathol 1999; 18:232-239.

36 Spira PJ, Sharpe DM, Halliday G, Cavanagh J, Nicholson GA: Clinical and pathological features of a Parkinsonian syndrome in a family with an Ala53Thr alpha-synuclein mutation. Ann Neurol 2001;49:313-319.

37 Ohtake H, Limprasert P, Fan Y, Onodera O, Kakita A, Takahashi H, Bonner LT, Tsuang DW, Murray IV, Lee VM, Trojanowski JQ, Ishikawa A, Idezuka J, Murata M, Toda T, Bird TD, Leverenz JB, Tsuji S, La Spada AR: Beta-synuclein gene alterations in dementia with Lewy bodies. Neurology 2004;63:805811.

38 Galvin JE, Lee SL, Perry A, Havlioglu N, McKeel DW Jr, Morris JC: Familial dementia with Lewy bodies: clinicopathologic analysis of two kindreds. Neurology 2002;59:10791082.

39 Kruger R, Schols L, Muller T, Kuhn W, Woitalla D, Przuntek H, Epplen JT, Riess O: Evaluation of the gamma-synuclein gene in German Parkinson's disease patients. Neurosci Lett 2001;310:191-193.

40 Kruger R, Kuhn W, Muller T, Woitalla D, Graeber M, Kosel S, Przuntek H, Epplen JT, Schols L, Riess O: Ala30Pro mutation in the gene encoding alpha-synuclein in Parkinson's disease. Nat Genet 1998;18:106-108

41 Brett FM, Henson C, Staunton H: Familial diffuse Lewy body disease, eye movement abnormalities, and distribution of pathology. Arch Neurol 2002;59:464-467.

42 Tsuang DW, Dalan AM, Eugenio CJ, Poorkaj P, Limprasert P, La Spada AR, Steinbart EJ, Bird TD, Leverenz JB: Familial dementia with lewy bodies: a clinical and neuropathological study of 2 families. Arch Neurol 2002; 59:1622-1630.

43 Bonner LT, Tsuang DW, Cherrier MM, Eugenio CJ, Du Jennifer Q, Steinbart EJ, Limprasert P, La Spada AR, Seltzer B, Bird TD, Leverenz JB: Familial dementia with Lewy bodies with an atypical clinical presentation. J Geriatr Psychiatry Neurol 2003;16:59-64.

44 Denson MA, Wszolek ZK: Familial parkinsonism: our experience and review. Parkinsonism Relat Disord 1995;1:35-46. 
45 Denson MA, Wszolek ZK, Pfeiffer RF, Wszolek EK, Paschall TM, McComb RD: Familial parkinsonism, dementia, and Lewy body disease: study of family G. Ann Neurol 1997;42:638-643.

46 Inose T, Miyakawa M, Miyakawa K, Mizushima S, Oyanagi S, Ando S: Clinical and neuropathological study of a familial case of juvenile parkinsonism. Jpn J Psychiatry Neurol 1988;42:265-276.

-47 Mizutani T, Inose T, Nakajima S, Gambetti P: Familial parkinsonism and dementia with 'ballooned neurons'. Adv Neurol 1993;60: 613-617.

-48 Zarranz JJ, Alegre J, Gomez-Esteban JC, Lezcano E, Ros R, Ampuero I, Vidal L, Hoenicka J, Rodriguez O, Atares B, Llorens V, Gomez Tortosa E, del Ser T, Munoz DG, de Yebenes JG: The new mutation, E46K, of alpha-synuclein causes Parkinson and Lewy body dementia. Ann Neurol 2004;55:164173.

-49 Aarsland D, Ballard CG, Halliday G: Are Parkinson's disease with dementia and dementia with Lewy bodies the same entity? J Geriatr Psychiatry Neurol 2004;17:137-145.

-50 Johnson J, Hague SM, Hanson M, Gibson A, Wilson KE, Evans EW, Singleton AA, McInerney-Leo A, Nussbaum RL, Hernandez DG, Gallardo M, McKeith IG, Burn DJ, Ryu M, Hellstrom O, Ravina B, Eerola J, Perry RH, Jaros E, Tienari P, Weiser R, Gwinn-Hardy K, Morris CM, Hardy J, Singleton AB: SNCA multiplication is not a common cause of Parkinson disease or dementia with Lewy bodies. Neurology 2004;63:554-556.

-51 Spillantini MG, Schmidt ML, Lee VM, Trojanowski JQ, Jakes R, Goedert M: Alphasynuclein in Lewy bodies. Nature 1997;388: 839-840.

52 Moore DJ, West AB, Dawson VL, Dawson TM: Molecular pathophysiology of Parkinson's disease. Annu Rev Neurosci 2005;28: 57-87.
Gasser T: Genetics of Parkinson's disease. Curr Opin Neurol 2005;18:363-369.

54 Galvin JE, Lee VM, Trojanowski JQ: Synucleinopathies: clinical and pathological implications. Arch Neurol 2001;58:186-190.

55 Li J, Uversky VN, Fink AL: Effect of familial Parkinson's disease point mutations A30P and A53T on the structural properties, aggregation, and fibrillation of human alphasynuclein. Biochemistry 2001;40:1160411613.

56 Kotzbauer PT, Giasson BI, Kravitz AV, Golbe LI, Mark MH, Trojanowski JQ, Lee VM: Fibrillization of alpha-synuclein and tau in familial Parkinson's disease caused by the A53T alpha-synuclein mutation. Exp Neurol 2004;187:279-288.

57 Ostrerova-Golts N, Petrucelli L, Hardy J, Lee JM, Farer M, Wolozin B: The A53T alphasynuclein mutation increases iron-dependent aggregation and toxicity. J Neurosci 2000;20:6048-6054.

58 Paisan-Ruiz C, Jain S, Evans EW, Gilks WP, Simon J, van der Brug M, Lopez de Munain A, Aparicio S, Gil AM, Khan N, Johnson J, Martinez JR, Nicholl D, Carrera IM, Pena AS, de Silva R, Lees A, Marti-Masso JF, Perez-Tur J, Wood NW, Singleton AB: Cloning of the gene containing mutations that cause PARK8-linked Parkinson's disease. Neuron 2004;44:595-600.

59 Berg D, Schweitzer KJ, Leitner P, Zimprich A, Lichtner P, Belcredi P, Brussel T, Schulte C, Maass S, Nagele T, Wszolek ZK, Gasser T: Type and frequency of mutations in the LRRK2 gene in familiar and sporadic Parkinson's disease. Brain, in press.

60 Zimprich A, Biskup S, Leitner P, Lichtner P, Farrer M, Lincoln S, Kachergus J, Hulihan M, Uitti RJ, Calne DB, Stoessl AJ, Pfeiffer RF, Patenge N, Carbajal IC, Vieregge P, Asmus F, Muller-Myhsok B, Dickson DW, Meitinger T, Strom TM, Wszolek ZK, Gasser T: Mutations in LRRK2 cause autosomal-dominant parkinsonism with pleomorphic pathology. Neuron 2004;44:601-607.
61 Funayama M, Hasegawa K, Kowa H, Saito M, Tsuji S, Obata F: A new locus for Parkinson's disease (PARK8) maps to chromosome 12p11.2-q13.1. Ann Neurol 2002;51:296301.

62 Wszolek ZK, Pfeiffer RF, Tsuboi Y, Uitti RJ, McComb RD, Stoessl AJ, Strongosky AJ, Zimprich A, Muller-Myhsok B, Farrer MJ, Gasser T, Calne DB, Dickson DW: Autosomal dominant parkinsonism associated with variable synuclein and tau pathology. Neurology 2004;62:1619-1622.

63 Wakabayashi K, Kakita A, Hayashi S, Okuizumi K, Onodera O, Tanaka H, Ishikawa A, Tsuji S, Takahashi H: Apolipoprotein E epsilon4 allele and progression of cortical Lewy body pathology in Parkinson's disease. Acta Neuropathol (Berl) 1998;95:450-454.

64 Parsian A, Racette B, Goldsmith LJ, Perlmutter JS: Parkinson's disease and apolipoprotein E: possible association with dementia but not age at onset. Genomics 2002;79:458461.

65 Saunders AM, Schmader K, Breitner JC, Benson MD, Brown WT, Goldfarb L, Goldgaber D, Manwaring MG, Szymanski MH, McCown N, et al: Apolipoprotein E epsilon 4 allele distributions in late-onset Alzheimer's disease and in other amyloid-forming diseases. Lancet 1993;342:710-711.

-66 Corder EH, Saunders AM, Risch NJ, Strittmatter WJ, Schmechel DE, Gaskell PC Jr, Rimmler JB, Locke PA, Conneally PM, Schmader KE, et al: Protective effect of apolipoprotein E type 2 allele for late onset Alzheimer disease. Nat Genet 1994;7:180184.

67 Levy G, Louis ED, Mejia-Santana H, Cote L, Andrews H, Harris J, Waters C, Ford B, Frucht S, Fahn S, Ottman R, Marder K: Lack of familial aggregation of Parkinson disease and Alzheimer disease. Arch Neurol 2004; 61:1033-1039. 